дизайнеров. Грамотное рисование есть основное условие для плодотворной творческой деятельности дизайнера.

$$
* * *
$$

1. Анисимов Н.Н. Основы рисования. - М.: /Стройиздат/, 1974. - 156 с.

2. Анисимов О.С. Основы методологического мышления. - М.: Наука, 1989. -412 c.

3. Гавричков, А.А. Рисунок архитектора - одно из важнейших средств познания окружающего мира. Проблема синтеза искусств в архитектуре / А.А. Гавричков. - Л.: Академия художеств», 1976 - №6. C. 63-75.

4. Бархин Б.Г. Методика архитектурного проектирования. - М.: /Стройиздат/, -1993. - 438.

\title{
Гришина И.И. \\ Цветные пятна. Их размер и кофигурация в учебном задании «пятна пространства важнее Пятен предметов»
}

Нижегородский государственный архитектурно-строительный университет (Россия, Нижний Новгород)

doi: $10.18411 / \mathrm{sr}-10-12-2017-38$

idsp: 000001:sr-10-12-2017-38

Разнообразие светотеневых и цветовых впечатлений, с которыми сталкиваются обучающиеся на занятиях по дисциплине «Живопись» не должны копироваться и точечно переноситься на поверхность листа. Выполняя живописное задание, студенты работают с цветными пятнами предметов и пространства, выстраивают общую цветовую композицию, выявляют объем предметов и глубину пространства.

Студентам старшего курса направления бакалавриат Графический Дизайн по дисциплине «Живопись» было предложено экспериментальное задание под названием «Пятна пространства важнее пятен предметов». Суть задания заключалась в следующем; обучающимся предлагалось изобразить цветом натюрморт из трех - четырех предметов несложной формы стоящих в одну линию в условно-декоративной манере, где предметы и пространство решены цветными пятнами.

Но главная особенность данного задания - это пятна пространства при изображении должны быть важнее пятен предметов, т. е. пятна пространства должны быть объемнее и активнее пятен предметов и стремиться выйти на передний план.

Обращаясь к работам великих мастеров изобразительного искусства можно сделать вывод, что художники не одинаково относились к предметам и пространству. В одном случае, предметы занимали главенствующую позицию по отношению к пространству и изображались укрупнено и даже под обрез, на вылет. Примерами могут служить такие произведения искусства как «Богатырь» М. Врубеля, «Портрет жены» К. Петрова - Водкина, «Зеленый шум» А. Рылова. В другом случае, пространство верховодит по отношению к предметам в таких картинах, как «Масленица» Б. Кустодиева, «Вдовушка» П. Федотова, «Менины» Д. Веласкиса. В обоих случаях рассматривается размер, величина, т. е. много - мало.

В учебном задании же предлагается пространство сделать объемом, а предметы пространством.

Прежде, чем приступить к эскизированию, преподаватель проговаривает со студентами различные возможные варианты.

Выполнение задания строится на работе с цветными пятнами.

Цвет воздействует сильнее, нежели ахроматика. И как следствие, предметы могут стать ахроматичными, а фон цветной.

Техника письма в живописи построена так, что предметы переднего плана пишутся корпусно, а пространство - жидко, мягко, лессировочно. Если же есть предметы на дальнем плане, то они списываются с пространством. В предлагаемом задании 
предметы заднего плана отсутствуют, т. к. в натюрморте они выстроены в линию, тогда фон может писаться мазисто, предметы - жиденько или лессировочно.

Размер пятен предметов и пространства студенты выбирают сами соответственно с замыслом, а именно: пятна предметов крупнее пятен пространства, или же наоборот.

Светотень на предметах может быть, но она не должна лепить объем.

Предлагается использовать свойства цвета - пятна холодных цветов зрительно будут удаляться, а теплые приближаться.

Обращается внимание студентов на касания пятен и их конфигурацию, абрис.

А так же пятна пространства могут иметь выпуклую форму, а пятна предметов держать поверхность или утопать в ней.

Еще рассматривается такой вариант, где пятна пространства между предметами образуют по рисунку предмет.

Для выразительности и достижения цели может применяться разная по толщине и контрасту по тону и цвету обводка.

Ввести такое задание подсказала практика. Студенты компонуют, рисуют и пишут предметы натюрморта, а пространство игнорируют. Оно существует в учебных заданиях само по себе. Пятна пространства между предметами не отслеживаются, с углами формата не работают, края листа композиционно не продумываются.

Это задание «Пятна пространства важнее пятен предметов» основано на ведении хода выполнения живописного задания от обратного. Студенты должны выстроить стройную систему поэтапного выполнения живописного задания.

Как выяснилось, такое задание помогает укрепить академическую базу, расширить знания в декоративной живописи, развивать фантазию, проявить творчество и индивидуальность.

Давыдова М.А.

Семья и детский как два важнейших компонента в эстетическом образовании детей дошкольного возраста

ГБОУ Школа № 117 ДО № 1

(Россия, Москва)

doi: $10.18411 / s r-10-12-2017-39$

idsp: 000001:sr-10-12-2017-39

\section{Аннотация}

В данной статье раскрываются семья и детский сад как два важнейших компонента в эстетическом образовании детей дошкольного возраста.

Ключевые слова: эстетическое образование; семья; родительская компетентность, сотрудничество; дошкольная организация.

Эстетическое образование - одна из важнейших сторон многогранного процесса становления личности, эстетического осознания прекрасного, развитие художественного вкуса и умения творчески создавать продукты ручного творчества. Дошкольный возраст очень важный этап в развитии и воспитании личности, а также наиболее благоприятный для формирования художественно-эстетической культуры, поскольку именно в дошкольном возрасте у ребенка преобладают позитивные эмоции, появляется особая чувствительность к языковым и культурным проявлениям, личная активность, происходят качественные изменения в творческой деятельности.

Очевидно, большое значение имеет воспитание эстетической восприимчивости, в первую очередь, в семье. Анализ ряда исследований современности (Арнаутовой Е.П., Дубровой В.П., Коломийченко Л.В. и других) позволяет обобщить взгляды на понимание педагогической компетентности, которая представляет собой в единстве теоретическую и практическую готовность к осуществлению воспитания, т.е. понимание и осознание ответственности за воспитание своих детей; знания о развитии, воспитании и обучении 